„Kwartalnik Filmowy” nr 110 (2020)

ISSN: 0452-9502 (Print) ISSN: 2719-2725 (Online)

https://doi.org/10.36744/kf.314

(c) Creative Commons BY-NC-ND 4.0

\title{
Aleksander Kmak
}

Uniwersytet Warszawski

https://orcid.org/oooo-0003-3724-5397

\section{Kryzys reprezentacji, Ziemia- -krajobraz i posthumanis- tyczny panteizm w La Région centrale Michaela Snowa}

\author{
Slowa kluczowe: \\ teoria filmu; \\ film awangardowy; \\ Michael Snow; \\ krajobraz; \\ antropocen; \\ zmysłowa teoria \\ filmu
}

\begin{abstract}
Abstrakt
Autor omawia film Michaela Snowa La Région centrale. Przywołując różne opracowania dotyczące filmu, koncentruje się na tym, co pozostało poza obszarem zainteresowania ich autorów, mianowicie na zmysłowym wymiarze doświadczenia tego filmu i jego konsekwencjach dla statusu kina jako przestrzeni poznawania rzeczywistości. La Région centrale zostaje zestawiony z koncepcją malarskiej katastrofy i obrazu-diagramu Gilles'a Deleuze'a, a celem tego zestawienia jest wskazanie, jak doświadczenie krajobrazu w filmie staje się posthumanistycznym projektem konstruowania nowego świata, w którym dotychczasowe dualizmy ciała i umysłu, podmiotu i przedmiotu, człowieka i zwierzęcia zostaja w pełni odrzucone. Interpretacji towarzyszy namysł nad rolą kina w epoce antropocenu i próba dowartościowania tradycji realizmu w teorii filmu.
\end{abstract}


I to właśnie z chaosu wychodzi najpierw "uporczywa geometria", "linie geologiczne"; i ta geometria i geologia same musza przejść przez katastrofe, aby wydobyć kolory, aby ziemia wzniosta się do stońca. ${ }^{1}$

O posthumanistycznych perspektywach monumentalnego, trzygodzinnego filmu La Région centrale (1972) Michaela Snowa nie sposób pisać bez odniesienia go do bardziej znanego eksperymentu artysty - pochodzącej z 1967 r. Długości fali (Wavelength). Pierwszy z wymienionych filmów cechuje znacznie większy stopień radykalizmu formalnego, co pozwala wyeksponować jego posthumanistyczną myśl, zawartą przede wszystkim w procesie wyobcowywania widza zaangażowanego zmysłowo.

Zanim jednak przejdę do tego filmu, sprawiającego analityczne trudności - jak bowiem argumentować za posthumanizmem przefiltrowanym przez jak najbardziej ludzkie zmysły? - chciałbym przypomnieć, że w wymiarze wizualnym czterdziestominutowa Długość fali została oparta na montażu powolnych, wymykających się świadomemu postrzeganiu zbliżeń realizowanych przez nieruchomą kamerę ustawioną w pokoju. Upływ czasu - ujmowany nie bez powodu jako podstawowy temat filmu, przez samego autora nazywanego wręcz „pomnikiem czasu" $^{\prime 2}$ - podobnie jak samo zbliżenie dokonywane przez kamerę, nie jest bynajmniej spójny. Przeciwnie, wpadające do pomieszczenia przez duże okna światło dzienne wskazuje na zmianę pór dnia, a w końcu ustępuje ciemności nocy przemieniającej owe okna w puste, czarne płaszczyzny. Co więcej, w niektórych momentach obraz mieszkania odznacza się zaburzającą immersję saturacją koloru, rozświetlając się jasnym różem lub bursztynowym złotem. Przypomina wtedy tworzoną w tym samym czasie przez Andy'ego Warhola serię wydruków i obrazów przedstawiających krzesło elektryczne $\mathrm{w}$ różnych wariacjach prześwietleń kolorystycznych, czasem tak silnych, że krzesło - podobnie jak wnętrze pokoju u Snowa - staje się prawie nierozpoznawalne. Zabiegi montażowe ostentacyjnie nie korespondują z tym, co zostaje zasugerowane jako szkielet fabuły filmowej. Na początku do pomieszczenia zostaje wniesiona półka (postaci to pojawiają się przed kamera, to znikają). Mniej więcej w połowie filmu dochodzi prawdopodobnie do śmierci jednego z bohaterów, kamera zaś cały czas wykonuje zbliżenie, wykrawając w kadrze coraz mniejszy fragment przestrzeni oraz ignorując wszystko, co z perspektywy narracji mogłoby się okazać interesujące. Najlepszym przykładem obranej przez Snowa strategii obrazowania jest finał, a raczej to, czym kończy się film, bo trudno mówić tu o jakimkolwiek rozstrzygnięciu w fabule. Oko kamery zbliża się do zawieszonej na ścianie fotografii wybrzeża i fal obmywających brzeg, a kiedy wreszcie tam dociera, niejako kontynuuje pochód, przekraczając niewidzialną granicę, za którą obraz traci konkretny kształt i ostatecznie rozmywa się $\mathrm{w}$ radykalnym zbliżeniu, przekształcając $\mathrm{w}$ plamę. $\mathrm{W}$ fotografii wody nie ma nic interesującego, a dla niezaspokojonej ciekawości kamery nie sposób znaleźć - jak się wydaje - jakiegokolwiek (zrozumiałego) uzasadnienia.

Najważniejszym w kontekście posthumanizmu zagadnieniem jest tu z pewnością doprowadzenie perspektywy do jej funkcjonalnej skrajności. Narzędzie wywiedzione z renesansowej teorii malarstwa - według Erwina Panofsky'ego stabilizujące $\mathrm{w}$ sztuce i filozofii pojęcie autonomicznego, racjonalnego podmiotu ${ }^{3}$ - w filmie Snowa nie służy budowaniu realizmu. Wbrew teorii aparatu Jean-Louis 
Baudry'ego perspektywa nie wytwarza tu iluzji wiarygodnej przestrzeni ani nie czyni z widza wyizolowanego z niej podmiotu marzącego o władzy nad przedstawieniem. Przeciwnie, Długość fali jest metaforycznym obrazem tego, czego zobaczyć ani nad czym zapanować nie można - przez nierozwiązywalną zagadkę motywacji ciągłego zbliżenia i kończące się niepowodzeniem poszukiwanie znaczenia możliwego do odczytania z obrazu opowiada o zawodności władz poznawczych napotykających granicę, poza którą załamują się wszystkie stabilne kategorie. Podmiot patrzący rozprasza się w nieprzeniknionym obrazie, widz zostaje skonfrontowany z nieprzystawalnością własnej - wizualnej, ale i mentalnej perspektywy i obcego spojrzenia instancji widzącej.

Tym samym Długość fali otwiera się na interpretację posthumanistyczna, w której istotna jest kwestia podmiotu spoglądającego. Waga gestu Snowa nie polega bowiem wyłącznie na tym, że wykracza on poza nowożytny racjonalizm, jako że w całkowitym odrzuceniu perspektywy można odnaleźć coś bardziej radykalnego - próbę skonstruowania obrazu całkowicie nie-ludzkiego. Podkreślają to zaskakujące zabiegi wplatania w fabułę mikronarracji ignorowanych przez kamerę. Na cóż bowiem wskazują one, jeśli nie na obcość, inność i odrębność depozytariusza spojrzenia? Wcale nie chodzi tu o zakwestionowanie granic dotychczasowego podmiotu w celu jego odbudowy na innych zasadach - jako ucieleśnionego i materialnie obecnego w przestrzeni. W Dtugości fali Snow zmierza raczej do odrzucenia podmiotu jako kategorii z gruntu antropocentrycznej. Umowny finał filmu sugeruje, że w amorficznej plamie fal współistnieją różne siły, niekoniecznie odnoszące się do czegokolwiek, co można byłoby wyróżnić jako podmiot. Rozmazany, wymykający się znaczeniu obraz uruchamia skojarzenia haptyczne, a bezkształtna pozostałość fotografii wydaje się płaszczyzną domagającą się raczej dotyku niż spojrzenia. Jednocześnie w umykającej linii fal ludzkie rozróżnienie na poszczególne zmysły zostaje zniesione - patrzenie przechodzi płynnie w aktywność taktylna, zawodzi zmysł równowagi skonfrontowany z przestrzenią pozbawioną jakiegokolwiek punktu odniesienia, w której różnice między stroną lewą a prawa, górą a dołem, głębią a powierzchnią tracą jednoznaczność. Taka przestrzeń nie służy formowaniu (nowej) podmiotowości, ponieważ to, co z niej pozostało, jest już w tę przestrzeń wetkane, podobnie jak fala nie stanowi autonomicznego zjawiska, będąc tylko ruchem cząsteczek wody. Film Snowa staje się w ten sposób radykalnym ćwiczeniem z posthumanizmu, obrazem „nieskrojonym pod ludzkie oko”, niedotyczącym ludzkich spraw, lecz eksplorującym możliwości innej perspektywy.

Ogniwem łączącym Dtugość fali i La Région centrale jest wyjście poza ludzką instancję widzącą. W obydwu przypadkach widz odczuwa nieprzystawalność swojego ciała do perspektywy podmiotu patrzącego. Strategię tę omówię bardziej szczegółowo w dalszej części artykułu, nawiązując do konkretnych zabiegów obecnych w drugim z filmów. W tym miejscu chciałbym jednak uargumentować powyższe spostrzeżenie. Idea przekroczenia przez człowieka granic ciała i zmysłów wydaje się paradoksalna, ale - jak pokazuje już Długość fali-umożliwia nie tylko konstrukcję nieantropocentrycznego podmiotu, lecz także bliskie spotkanie z nim. Wydaje się bowiem, że w podejściu Snowa istotne jest stworzenie w znoszącym trudy seansu filmowego ciele widza obszaru dla aktywności czegoś innego, uwidocznionego szczególnie wyraźnie w momentach, w których ciało to odmawia po- 
słuszeństwa, przypominając jednocześnie o swoim istnieniu. Mam tu na myśli zarówno ostatnią scenę Długości fali, w której u widza dochodzi niejako do pomieszania zmysłów, jak i nieustający ruch kamery w La Région centrale, mogący wprawić odbiorcę w stan podobny do zawrotu głowy. W samej odczuwanej nadmiernie obecności ciała trudno rzecz jasna doszukiwać się przekroczenia granic człowieczeństwa, ale w silnym powiązaniu ciała z obrazem, w którym niełatwo określić granicę między jednym i drugim, już tak. Ilustruje to powtarzający się w La Région centrale motyw białego znaku „, $\mathrm{x}^{\prime}$ na czarnym tle, który wyznacza interwały między poszczególnymi ujęciami, a do którego powrócę pod koniec eseju. Wywołuje on u widza powidok deformujący oglądany przez niego później krajobraz. W momentach intensywnego przecięcia różnych rodzajów sprawczości niezależnych od woli widza, działania filmu jako obrazu czy diegetycznej instancji widzącej - w ciele odbiorcy dochodzi, jak sądzę, do wykształcenia poczucia niedającej się oswoić obcości destabilizującej dotychczasowe działanie zmysłów. Ich zawłaszczenie przez coś innego i zintensyfikowanie odczuwania sensualnego u odbiorcy jest tu - być może nie do końca oczywistą - furtką prowadzącą do doświadczenia, w którym zmysły nie podporządkowują się już logice usankcjonowanej przyzwyczajeniami ciała i przekraczają ludzki podmiot.

Przecięcie różnych sprawczości - w tym także tych należących do obrazów filmowych - może być argumentem na rzecz pogłębienia refleksji o przełamywaniu perspektywy antropocentrycznej. Jeśli bowiem ciało widza rzeczywiście staje się płaszczyzną różnych wpływów (tracąc przy tym swój jednoznacznie autonomiczny charakter i spójność własnych granic), nieantropocentryczny punkt widzenia okazuje się niewystarczający jako trop interpretacyjny. Filmy Snowa zawierają propozycję posthumanistycznego projektu kompozycji różnych sprawczości i instancji, wielorakich perspektyw, a także - co dziś, pięćdziesiąt lat po ich powstaniu, szczególnie ważne - odmienny sposób myślenia o świecie i odpowiedzialności za niego, która spoczywa na człowieku już nie jako ukoronowaniu stworzenia, ale jednej z jego wielu artykulacji. Zaskakujące jest to, że punktem wyjścia okazuje się tu jedna z najbardziej ludzkich aktywności - bliska, cielesna wręcz relacja z obrazami. O ile Michael Sicinski w artykule o Dtugości fali pisze o filmie jako o przestrzeni zagospodarowywanej przez widza ${ }^{4}$, o tyle w La Région centrale ciało staje się przestrzenią uobecnienia czegoś innego, czegoś, co sprawia, że nie tylko przestaje ono należeć do podmiotu, lecz pod wpływem intensywności obrazu „rozpływa się" w świecie.

Wobec braku jakichkolwiek sugestii dotyczących fabuły najważniejszym aspektem La Région centrale staje się (jeszcze wyraźniej niż w przypadku Długości fali) forma filmowa. Trzygodzinny obraz składa się z siedemnastu ujęć różnej długości, przedzielonych czarnymi planszami z białym znakiem „,x”. W zasięgu usytuowanej w jednym miejscu kamery pozostaje wyłącznie bliskie otoczenie kanadyjskie pustkowie. Na ekranie widzimy na przemian pokrytą kamykami ziemię, częściowo porośnięte formacje skalne, znajdujące się w dolinie jezioro oraz bezkres stopniowo zmieniającego kolory nieba. W filmie niezwykle ważny jest ruch - ciągły, nie licząc znaczących pauz między ujęciami, właściwie nieprzerywany, uzyskany przez zamontowanie kamery na specjalnie skonstruowanym przez Snowa i Pierre'a Abeloosa wysięgniku, umożliwiającym niemal dowolne ruchy aparatu: pionowe, poziome, rotacyjne, okrężne. O ile zatem seans Dtugości 
fali należałoby uznać za rodzaj transu stasis, bo obecny w filmie, nieustanny ruch jest dostrzegany dopiero z perspektywy czasu, o tyle recepcja La Région centrale przypomina raczej deliryczne doświadczenie zawrotu głowy. Każde z ujęć eksponuje inny zestaw ruchów kamery, a cały film przyjmuje formę zbliżoną do muzycznego crescendo - od bardzo powolnego sondowania podłoża płaskowyżu w pierwszych kilkudziesięciu minutach do niesłychanie szybkiego obrotu kamery, czyniącego z różnicy między widokiem nieba i ziemi coś w rodzaju efektu stroboskopowego w finale. Ścieżka dźwiękowa składająca się z metalicznych, robotycznych dźwięków towarzyszących ruchom wysięgnika wzmaga wrażenie powstające pod wpływem spojrzenia kamery. Filmowy materiał La Région centrale jest efektem pięciodniowej rejestracji dokonanej w październiku 1969 r., a trzy godziny zostały zmontowane z dwukrotnie dłuższej, „,surowej” całości. Poza narastającym rytmem film zachowuje rygor linearności czasu: pierwsze chwile odpowiadają mniej więcej momentowi, w którym słońce stoi w zenicie, następne ujęcia ilustrują kolejno popołudnie, wieczór, noc i poranek.

Tropy posthumanistyczne $\mathrm{w}$ interpretacji La Région centrale są oczywiste. Kluczowym zagadnieniem, akcentowanym w dotychczasowej recepcji filmu, pozostaje wybór lokacji. Nieprzypadkowo przecież aparatura Snowa i Abeloosa została zainstalowana w miejscu, z którego rozciąga się rozległy widok na obszar bez najmniejszego śladu wpływu czy bytności człowieka. Bezdroża Kanady stają się tu światem, który należy pojmować w skali zupełnie innej niż ludzka, pogrążonym w geologicznym długim trwaniu - ukazane tu wschody i zachody słońca może oddzielać zarówno kilkanaście godzin, jak i setki tysięcy lat, a wszelkie zmiany, choć niewątpliwe, są niedostrzegalne dla podmiotu operującego ludzką miarą czasu. Dlatego też pojawiający się co jakiś czas w kadrze cień wielkiego wysięgnika (sama maszyna, co znaczące, nie jest nigdy widoczna na ekranie) tak zaburza ten porządek.

Interesującym, choć niestety ignorującym kwestię oddziaływania filmu, przykładem skontekstualizowania obrazu Snowa jest artykuł Floriana Leitnera. Autor już w samym tytule - A Posthuman Perspective on Camera and Image Movement after Michael Snow's "La Région centrale” - jasno daje do zrozumienia, że mamy tu do czynienia z myśleniem o kinie wykraczającym poza antropocentryzm. Głównym powodem tego rodzaju spojrzenia jest według Leitnera praca kamery, która nie tylko nie symuluje działania ludzkiego aparatu widzenia, lecz przeciwnie zajmuje coraz to inne pozycje niemożliwe dla człowieka, zaciera granice między widzeniem, ruchem, myśleniem i odczuwaniem ${ }^{5}$. Wyjście poza antropocentryzm jest tu zatem możliwe dzięki stworzeniu innej relacji między obrazem a znaczeniem - w wymiarze wizualnym La Région centrale aktywnie i na bieżąco wytwarza sens przez sam ruch, nie oferując żadnego ludzkiego znaczącego. Jednocześnie odbiorca zostaje wytrącony z równowagi percepcyjnej, znajduje się w sytuacji, w której patrzenie nie jest równoznaczne z rozumieniem (wbrew językowi angielskiemu, w którym czasownik to see może oznaczać obie aktywności), a znaczenie staje się umowne, nietrwałe, płynne ${ }^{6}$. Analizując widzenie jako działanie zapętlone i samozwrotne, niekoniecznie pomagające $\mathrm{w}$ dociekaniu sensu zewnętrznego wobec niego samego, Snow przekracza - według Leitnera - wpisany w kino antropocentryzm, snując refleksję o możliwościach zdehumanizowanego spojrzenia, którego motywacja, tryb działania, a także ogniska zainteresowania pozostają dla 
widzów niepoznane i - być może - niepoznawalne. Symptomem zapaści sensu skoncentrowanego na człowieku jest dla badacza ostatnie ujęcie La Région centrale. Ukazane w nim rozświetlone niebo nie stanowi już właściwie żadnego konkretnego widoku, optycznie uchwytnego sensu, stając się płaskim tableau błękitu lub nawet - jak podpowiada Leitner - nie-obrazem ${ }^{7}$.

A jednak film Snowa nie jest według badacza spełnieniem posthumanistycznej perspektywy w kinie, ponieważ został obarczony jak najbardziej antropocentryczna, autorską genezą - człowiek przecież nie tylko wprawił maszynę $\mathrm{w}$ ruch i zmontował nagrany materiał, ale też gotowy film jest sygnowany nazwiskiem uznanego artysty przejmującego tym samym całość sprawstwa ${ }^{8}$. Wydaje się zatem, że film "posthumanistyczny" wymaga gruntownego przemyślenia, a może należałoby zupełnie odrzucić kino jako instytucję siłą rzeczy związaną z antropocentrycznym myśleniem o ruchomych obrazach. Ten sposób oglądu potwierdza podawany przez Leitnera przykład, mający zobrazować bardziej rozproszone i egalitarne sprawstwo posthumanistycznych „aktorów". Chodzi o nagranie pochodzące z aparatu cyfrowego zgubionego w $2010 \mathrm{r}$. przez niderlandzkiego turystę w czasie nurkowania u wybrzeża jednej z wysp Małych Antyli, który przebywszy niemal dwa tysiące kilometrów, został wyłowiony na Florydzie 9 . Znalazca opublikował w sieci film powstały w czasie dryfu kamery „operowanej” przez pewien czas przez żółwia, a zakończony (w chwili wyczerpania baterii) długim, zaskakująco podobnym do tego z La Région centrale ujęciem nieba, przykrywanego od czasu do czasu przejrzystą warstwą morskiej wody. Nagranie to jest według Leitnera o wiele pełniejszym, bo niejako praktycznym zastosowaniem posthumanistycznej koncepcji usieciowionego oddziaływania zróżnicowanych podmiotów ${ }^{10}$. Na płaszczyźnie wizualnej oba filmy są podobne, bowiem łączą w sobie nieskoordynowane - z ludzkiego punktu widzenia - ruchy kamery, zaburzenie orientacji w przestrzeni niepoddanej perspektywie ciała człowieka, a także obrazowanie obszarów usytuowanych poza sferą ludzkiej aktywności. Fundamentalna różnica między nimi polega natomiast - jak zauważa Leitner - na odmiennych sposobach egzekwowania autorstwa i sprawczości. „Morski” film jest bowiem węzłem splatającym działalność człowieka, zwierzęcia, oceanu i maszyny, a osadzająca La Région centrale $\mathrm{w}$ koleinach antropocentrycznej perspektywy artystyczna intencja Snowa zostaje w nim zastąpiona asamblażem dążeń, potrzeb, instynktów i pragnień, w tym także tych, które nie dają się rozpoznać w prosty sposób. Film ten wyraźnie odstaje od idei kina jako instytucji dystrybuującej obrazy - pojawił się w sieci, związanej przecież z innym modelem obcowania z reprezentacjami wizualnymi, w którym tradycyjna, wertykalna struktura relacji nadawca - odbiorca zostaje zmieniona w układ horyzontalny. Badacz stwierdza, że tym, co w „morskim” filmie najbardziej fascynujące, nie są ruchome obrazy, lecz obrazy w ruchu, droga, którą przebyły, zarówno z uwagi na udział różnych „aktorów”, jak i znaczny dystans geograficzny ${ }^{11}$. To droga unaoczniająca nowe znaczenie filmu jako dzieła wędrownego lub - żeby sięgnąć po sformułowanie używane w kontekście refleksji posthumanistycznej przez Rosi Braidotti - nomadycznego, czyli takiego, które wykształca tylko przejściowe tożsamości ukonstytuowane w relacji z innymi podmiotami ${ }^{12}$. Dopiero zestawienie różnych rodzajów sił sprawczych przynosi bowiem realną jakościową przemianę filmu w medium zdolne do przekroczenia granic antropocentryzmu. 
Trudno nie zgodzić się z obserwacjami Leitnera na temat warunków powstawania porównywanych filmów - w tym ujęciu La Région centrale okazuje się istotnie dziełem paradoksalnie tradycyjnym, wpisanym w kanon utrwalający antropocentryczny obraz świata. Jak jednak zamierzam wykazać, właśnie pozornie konserwatywne kinowe doświadczenie La Région centrale umożliwia nie tylko dogłębne zrewidowanie stanowiska w sprawie odbioru tego filmu, lecz przede wszystkim pomyślenie kina na nowo, jako przestrzeni zmysłowego spotkania z obcością. Trzygodzinne nadwerężenie ciała i zmysłów widza doprowadza do ekstazy w jej ścisłym znaczeniu ع̌k $\sigma \tau \alpha \sigma \iota \varsigma$ jako wyjścia z siebie. Zachęca nie tyle do „wejścia” w filmowy krajobraz, ile stania się tożsamym z tymże. Seans La Région centrale nie jest bowiem wcale doświadczeniem immersyjnym, lecz właśnie repulsywnym, wymiotnym, „katapultującym” z pozycji podmiotowej i prowokującym do stania się krajobrazem, przy bezgranicznej afirmacji automatyzmu medium filmowego i jego konsekwencji.

Zmysłowe zaangażowanie w film prowadzi ponadto do namysłu nad kwestią jeszcze bardziej fundamentalną - ontologią kina, dla której podstawową kategorią jest jego automatyzm, cecha konstytutywna dla La Région centrale. Pojęcie to, wielokrotnie powracające we wszystkich teoriach spod znaku realizmu, przede wszystkim zaś u Siegfrieda Kracauera i André Bazina, może wydawać się dziś przestarzałe, niemniej jego waga ujawnia się na nowo, co zauważył w ostatniej wydanej przed śmiercią książce Thomas Elsaesser, pisząc o zwrocie filozoficznym w teorii filmu. Chociaż idea automatyzmu i realizmu przestała interesować jej przedstawicieli w drugiej połowie XX w., ciągle była obecna w refleksji filozoficznej, stanowiącej współcześnie - według Elsaessera - istotny wątek namysłu nad ruchomymi obrazami. Jak zauważa badacz, rozpatrywany na gruncie teorii klasycznych automatyzm kamery umożliwiał skonstruowanie stabilnego obrazu świata oraz uznanie go za wiarygodny i trwały; tym samym kino stawało się antidotum na ontologiczny sceptycyzm ${ }^{13}$. Powrót refleksji nad automatyzmem i realizmem nie oznacza jednak w żadnym razie ponownego usankcjonowania tradycyjnych dualizmów humanistycznych: podmiotu i przedmiotu, widza i obrazu. Realność świata według Elsaessera w kinie jest możliwa wtedy, gdy widz zostaje pozbawiony własnej, jednostkowej podmiotowości, zgadzając się na brak natychmiastowego sensu oraz pozwalając na przepływ obrazów, których sam okazuje się częścia, na konfrontację z bezpośrednim jawieniem się realności, której ludzka instancja nie jest do niczego potrzebna ${ }^{14}$. Uczony zresztą odnosił się wprost do zakwestionowania antropocentrycznej perspektywy, zauważając, że potraktowanie filmów jako aktywnych elementów, a nie ilustracji realnego świata, nadaje im żywotność wykraczającą poza humanistyczną hierarchię władzy między podmiotem a przedmiotem ${ }^{15}$.

Istotną strategią negocjacji znaczeń w kontekście realizmu jest w La Région centrale „wytwarzanie” krajobrazu. Jak zauważa Piotr Schollenberger, patrzenie na krajobraz nigdy nie jest prostym, jednokierunkowym doświadczeniem opartym na wzajemnym przeciwstawieniu widza i rozpościerającego się przed nim obrazu. Przeciwnie, przeżycie krajobrazu jest zawsze doświadczeniem pochodzącym z wnętrza, percepcja zostaje w nie włączona, a widz zawsze spostrzega tyleż krajobraz, ile siebie samego jako jego nieodłączny element ${ }^{16}$. Jednak w przeżycie estetyczne wpisana jest także alienacja - wyobrażenie braku przynależności do świata, 
własnej odrębności i dystansu między podmiotem a przedmiotem spojrzenia. Fenomenologia zakłada istnienie pewnego nieprzekraczalnego interwału sprawiającego, że dotyk - związany z bliskością i namacalnością - staje się w ogóle możliwy, głębię, w której dotykajacy i dotykany się spotykają ${ }^{17}$. Ta uwaga prowokuje Schollenbergera do konstatacji, że w krajobrazie spełnia się auratyczność, rozumiana tak, jak zdefiniował ją Benjamin - jako naprzemienność czy wręcz jednoczesność zbliżenia i oddalenia, obcości i swojskości, moc przyciągania ze strony obiektu, ale i jego nieprzekraczalne odizolowanie ${ }^{18}$. Aura krajobrazu tłumaczy też jego potencjał afektywny - jeżeli człowiek funkcjonuje w przestrzeni geograficznej, nieprzenikniony, auratyczny krajobraz staje się obszarem powstawania niemożliwych do uporządkowania wrażeń oddziałujących na poziomie bardziej pierwotnym niż podmiotowy: krajobraz pozostaje przestrzenia nieoswojona, pre-antropologiczna o tyle, o ile w krajobrazie nie ma "osób", ponieważ nie można jeszcze w nim być sobą ${ }^{19}$.

Dlatego też doświadczeniu krajobrazu towarzyszy obezwładniający szok, niedający się wyrazić, który Schollenberger porównuje do rauszu lub narkotykowego zwidu ${ }^{20}$. Przestrzeń przestaje się rządzić prawami geometrii euklidesowej, traci punkty oparcia, a sam podmiot - kontrolę nad tym, czego doznaje. Krajobraz nie musi być zatem wystawionym na spojrzenie widokiem, raczej jawi się jako sposób doświadczania rzeczywistości ukazującej swoje niecodzienne, obce oblicze ${ }^{21}$. W tym miejscu myśl Schollenbergera zbiega się z koncepcją Lyotarda. Jeśliby bowiem rozróżnić między dwoma sposobami myślenia o przestrzeni - agoraskopięe ${ }^{22}$, w której przestrzeń dana jest do patrzenia, oraz agorapatię ${ }^{23}$, gdzie doświadczenie przestrzeni oddziałuje afektywnie i pochłania podmiot - francuskiemu myślicielowi bliższy jest ten drugi. Według teorii Lyotarda krajobraz jest rewersem codziennego $\dot{z}$ ycia ${ }^{24}$ polegającym na nagłym wyobcowaniu i zawieszeniu rozpoznania. Dające się zrozumieć znaczenie rzeczywistości zostaje tu przesłonięte materialną obecnością świata, tak mocno oddziałującego na zmysły, że niemożliwego do racjonalnego uporządkowania. Krajobraz nie jest zatem widokiem roztaczającym się przed widzem, lecz nagłym wtargnięciem przestrzeni w podmiot nierozpoznający ani otoczenia, ani siebie. Dzieje się tak wtedy, gdy w jakimś doświadczeniu zabraknie dobrze znanego i bezpiecznego sensu. Jak wówczas, kiedy wielokrotnie powtarzane słowo traci znaczenie, co służy wyodrębnieniu materialności dźwięku, dotychczas przez owo znaczenie zdominowanej. Lyotard porównuje tę sytuację do widoku Ziemi obserwowanej z powierzchni Księżyca, wsi postrzeganej przez mieszkańca miasta czy też miasta - przez rolnika ${ }^{25}$. We wszystkich przykładach dochodzi nie tylko do zachwiania stabilnych współrzędnych wyznaczanych codziennym doświadczeniem, lecz także ujawnienia obcej, niezrozumiałej podszewki świata. Wobec tego właściwości wyróżniające podmiot zostają w doświadczeniu krajobrazu zawieszone na rzecz przeżycia poza granicami jednostkowości.

Filozof odnosi się zresztą do filmu Snowa w artykule poświęconym teorii inscenizowania (mise-en-scène) jako politycznej praktyki wytwarzania wizualności. Twierdzi tam, że twórca La Région centrale nie wytwarza spójnej przestrzeni, a więc i obrazu koherentnego świata, ale raczej - podejmując tradycję sofistów i Nietzschego - demonstruje, że nie ma żadnej całości, istnieją tylko perspektywy o charakterze partykularnym ${ }^{26}$. Obraz filmowy wyzwala się według Lyotarda od mimetycznego przymusu prawdy i fałszu, prezentując to, co bez ingerencji aparatu pozostaje niedostrzegalne, a właściwie nie istnieje ${ }^{27}$. Szokujące wrażenie powodo- 
wane przez krajobraz opiera się więc na fundamentalnym braku całościowego przedmiotu doświadczenia. Ów brak paradoksalnie „,atakuje” widza powtarzającymi się obrazami tych samych rzeczy, których tożsamość jest jednak pozorna, ponieważ za każdym razem są one ujmowane w innej perspektywie, drastycznie je przekształcającej, do tego stopnia, że w najszybszych fragmentach filmu tracą one jakąkolwiek swoistość. Załamanie wszelkiej narracji, którą można byłoby wywieść z filmu Snowa - Lyotard pisał o poszczególnych mikro-opowieściach lasu, jeziora, ziemi $^{28}$ - jest związane $\mathrm{z}$ „usunięciem” tytułowego obszaru centralnego: kamera nie tylko nie obejmuje go w całości, lecz także krąży wokół niego po nieregularnej orbicie, nigdy nie wkraczając na jego teren. Centrum obszaru to labirynt ${ }^{29}-$ konstatuje filozof.

Nieprzerwany ruch w La région centrale odpowiada temu, co Lyotard ujmuje jako „,akino" - eksperymentalny obszar ruchomych obrazów. To, co widoczne na ekranie, przekracza tu własny sens przez zaprzeczenie totalności charakterystycznej dla tradycyjnej opowieści filmowej, w której nie ma miejsca na elementy przypadkowe lub niepotrzebne ${ }^{30}$. Ekscesywna wizualność wywołana naddatkiem ruchu lub - przeciwnie - jego zamarciem przekreśla wprawdzie mimetyczną przyjemność seansu, ale umożliwia ekstatyczne doświadczenie tego, co jeszcze niepomyślane, obezwładniające wrażenie związane z doświadczeniem krajobrazu jako momentem szoku poznawczego.

Schollenberger tak podsumowuje swoje uwagi: krajobraz w filmie Snowa nie stanowi wyniku pogwałcenia zasad poprawnego przedstawienia. Jest raczej próba krytycznego namystu nad warunkami, które czynia przedstawienie możliwym. Warunki te poprzedzaja wszelka syntezę danych zmystowych, dzięki której ujmujemy je w jeden, spójny obraz. Tym samym należa do porządku doznawania lub odczuwania (Empfindung, sensation), w którym, można by powiedzieć, nie ma miejsca na osobę. Dokładniej: nie ma jednego miejsca, jest bowiem nieskończenie wiele niedajacych się złożyć w jedna spójna całość miejsc; nie ma jednego czasu, brak jest bowiem określonej linii narracyjnej, a czas zdaje sie płynać we wszystkich kierunkach; wreszcie nie ma osoby, gdyż ten, "kto patrzy", pozbawiony zostaje swego absolutnego punktu widzenia, jego status zewnętrznego obserwatora zostaje podważony, gdyż sam zostaje wpisany w obraz ${ }^{31}$.

Komentarz ten wydaje się zadowalający tylko częściowo - bardzo trafnie opisuje krajobraz jako pewien rodzaj doświadczania, wskazuje również na zabiegi zastosowane w filmie, ale nie zdaje sprawy ze sposobu, w jaki La Région centrale w samozwrotnej refleksji komentuje kino jako przestrzeń zmysłowego spotkania z obrazami. Przyjrzyjmy się sekwencji z ostatniej części filmu. Trwające około trzydziestu minut ujęcie rozpoczyna powolny, horyzontalny obrót kamery. Po chwili następuje zbliżenie na przypadkowy kamień i ponowne oddalenie (kamera wciąż się obraca), w końcu zaś ramię wysięgnika zaczyna wykonywać ruch obrotowy wokół własnej osi poziomej, zasygnalizowany dodatkowo pulsującym dźwiękiem. Kamera filmuje teraz pełen okrąg horyzontu, jednocześnie wykonując taką rotację, że w kadrze niebo i ziemia regularnie zamieniają się miejscami. Ruch aparatu stopniowo nabiera prędkości, osiągając kulminację w momencie, w którym kamera porusza się tak szybko i wykonuje tyle obrotów jednocześnie, że ziemia i niebo przeistaczają się w migotliwą całość. Ostatecznie wirowanie zwalnia, tak że z czasem staje się możliwe zidentyfikowanie poszczególnych obrazów. Film dobiega końca, podczas gdy kamera porusza się już spokojnie. Rozbrzmiewający w tej sek- 
wencji pulsujący dźwięk zaprogramowany przez Snowa początkowo rozlega się $\mathrm{w}$ regularnych odstępach, aby w fazie najszybszego ruchu aparatu nabrać tempa. Przerwy między poszczególnymi sygnałami stają się niemożliwe do zidentyfikowania, zlewając się w jeden przedłużony, burdonowy odgłos. Sekwencja ta jest, jak sądzę, swoistym zwornikiem filmu oraz najdobitniej eksponuje ten jego wymiar, w którym wychodzi on poza idę humanistycznego podmiotu widząco-myślącego. To wszystko odbywa się zaś w najmniej spodziewany sposób - przez ekstatyczne pobudzenie zmysłów i ciała widza.

Istotnym elementem tego procesu jest wyłaniająca się z przywołanych ujęć wizja spotkania obrazu i podmiotu, a także funkcji obrazu jako doświadczenia świata. Opisu chaotycznego przedstawienia krajobrazu z filmu Snowa nie wyczerpują konstatacje o jego delirycznym, halucynacyjnym potencjale czynione przez Schollenbergera i Lyotarda. Wydaje się, że La Région centrale jest propozycją jeszcze bardziej radykalna, zawierającą sugestię, że warunkiem skonstruowania krajobrazu jest jego absolutna destrukcja, stworzenie przestrzeni, w której może pojawić się coś nowego. Taki jest bowiem sens ostatniej sceny filmu, w której mamy do czynienia nie tyle z zamazaniem obrazu, ile całkowitym brakiem jego czytelności, „,krajobrazową miazgą", z której zniknęło wszelkie podobieństwo do oryginału. Istotne znaczenie ma tu także czasowy wymiar filmu Snowa - trzy godziny stanowią wyzwanie dla wytrzymałości widza. Finał nie jest zresztą bynajmniej doświadczeniem immersyjnym, ale czymś zgoła odwrotnym: zderzeniem z płaskością ekranu, na którym pojawiają się abstrakcyjne formy. Widz jako odbiorca świata diegetycznego przestaje istnieć, pozostaje tylko pokawałkowany podmiot nierozpoznający się do końca ani w świecie filmu, ani przed ekranem, wyobcowany zarówno „tam”, jak $\mathrm{i}$ „,tu”, przeciążony niespójnymi bodźcami wizualnymi. Niemożność zajęcia stabilnej pozycji powoduje w doświadczeniu wyrwę, w której ujawnia się fundamentalna obcość interesująca Snowa już w Długości fali.

Destrukcja, o której mowa, nie powinna budzić jednak w żadnym razie skojarzeń negatywnych. Jak bowiem wynika z opisanej sekwencji, niszczycielski potencjał krajobrazu umożliwia ujawnienie czegoś nowego, próbę stworzenia nowej perspektywy przy użyciu niespotykanej dotychczas optyki ${ }^{32}$. Nieantropocentryczne spojrzenie zakłada swobodne, synestezyjne przekraczanie granic poszczególnych zmysłów, dlatego może nie powinny dziwić podobieństwa między zniszczeniem krajobrazu w finale La Région centrale a koncepcją diagramu, którą wypracował Gilles Deleuze, pisząc o twórczości Francisa Bacona. Malarstwo twierdzi filozof - zawsze rozpoczyna się od katastrofy, wychodzi bowiem od momentu irracjonalnego umieszczenia na płótnie kresek, plamek, ułożenia ich losowo i swobodnie, tak że z początku nie są ani znaczącymi ani znaczonymi, pozostają poza sferą jakiejkolwiek komunikacji ${ }^{33}$. Katastrofa polega tu na podważeniu obrazu jako przedstawienia, załamaniu wszystkich możliwości poznawczych opartych na dominacji wzroku, wysunięciu na pierwszy plan malarskiego gestu unieważniającego pragnienie rozpoznania, identyfikacji, opowieści ${ }^{34}$. Tym właśnie jest etap diagramu - według Deleuze'a bodaj najważniejszy w pracy nad obrazem. Dochodzi na nim do wytworzenia płaszczyzny pozbawionej iluzji głębi, na której może zaistnieć wizualna Figura ${ }^{35}$. Co istotne, wizualność tej Figury nie jest równoznaczna z jej wymiarem optycznym - o ile ów oznaczałby funkcjonowanie figur (pisanych małą literą) w zrozumiałej, znaczącej całości, o tyle wizualność byłaby 
oddziaływaniem wzrokowym wyprzedzającym sens, możliwościa rzeczy ${ }^{36}$ (lub matter of $\left.f a t^{37}\right)$, w przypadku której przedmiot, Figura pisana wielką litera, jawi się $\mathrm{w}$ samym swoim byciu wizualnym ${ }^{38}$. Wyjście $\mathrm{z}$ kryzysu reprezentacji jest możliwe według filozofa na dwa sposoby. Pierwszy z nich polegałby na radykalnym wyczyszczeniu diagramu i skonstruowaniu w pełni syntetycznego ,"kodu”, jak w abstrakcji geometrycznej Mondriana czy Malewicza - drugi na maksymalnym rozszerzeniu diagramu przez destrukcję wszelkiej optycznej materii, jak w action painting Pollocka. Druga strategia zakłada, że płótno zastępuje rzeczywistość, stwarza mapę pokrywającą się z terytorium, co staje się dostrzegalne także w praktycznym geście zdejmowania obrazów ze sztalug i rozciąganiu ich na ziemi, co umożliwia malowanie $\mathrm{z}$ wnętrza przedstawienia - nastapiła tu bowiem przemiana horyzontu w ziemię: cały horyzont optyczny obrócił się w taktylna ziemię ${ }^{39}$.

Metafory Deleuze'a odzwierciedlają to, co można wyczytać z ekstatycznego ujęcia z filmu Snowa - nierozróżnialność obrazów nieba i ziemi, ruch kamery tak szybki, że wydaje się skierowany we wszystkie strony naraz. Wszystko to koresponduje z próbą stworzenia obrazu niepoddanego rzeczywistości, takiego, w którym rzeczywistość jest dopiero kształtowana. La Région centrale jest nie tylko przemianą horyzontu w ziemię, jak pisał o malarstwie Deleuze, lecz stworzeniem nowej Ziemi, nowych przestrzennych, ale i etycznych relacji, nowych form podmiotowości i komunikacji, w której prosty podział na zmysły zawodzi, a to, co wizualne, okazuje się jednocześnie haptyczne ${ }^{40}$.

Posthumanistyczne wyjście poza ustalone granice refleksji o podmiocie nie kończy się jednak na stworzeniu innej ontologii obrazu i relacji, w którą wchodzi z nim widz. Równie ważnym elementem byłaby tu bowiem odmienna konfiguracja jego ciała i materii filmowej. Odbiorca La Région centrale zostaje uobecniony cieleśnie w filmie za pomocą cięć montażowych przerywających ciągłość obrazów. Widok wspomnianego znaku ", $x^{\prime \prime}$ na czarnej planszy pojawiającej się między ujęciami utrzymuje się stosunkowo długo, bo około dwudziestu sekund. Po tym czasie u widza występuje powidok, który nakłada się na kolejne obrazy i nie znika przez kilkanaście sekund. Niebo wybrzusza się więc w formie iksa, ziemia komponuje się z krzyżowymi liniami. Interwały te pozwalają zaakcentować obecność patrzącego, który zaś patrzy tak, że samo spojrzenie (jego potencjał i zawodność) staje się działaniem samozwrotnym. Dlatego trudno też jednoznacznie mówić o immersyjnym charakterze La Région centrale, ekstatyczne poczucie siebie nie służy bowiem zanurzeniu w diegezie, lecz intensyfikuje odczucie ciała, które częściowo uniezależnia się lub staje nieposłuszne wobec świadomości. Jest również miejscem spotkania z obcościa, przestrzenia, w której poczucie zadomowienia okazuje się niemożliwe. Powraca tu diagram Deleuze'a - obraz, w którym trajektoria spojrzenia jest zgodna z ruchem ręki, myśl zostaje determinowana procesami cielesnymi, a dualistyczny podział na umysł i ciało - zniesiony. La Région centrale wytwarza zatem wizualny, ale nie optyczny obraz - reprezentację, w której zostaje zaakcentowana nieprzezroczystość medium, nie zaś rozpoznawalny widok. Wizualność ta ponadto silnie aktywizuje zmysłowy aparat widza zmuszonego do porzucenia tradycyjnej pozycji odbiorczej i odkrycia w swoim ciele przestrzeni o innym charakterze. To właśnie ten proces okazuje się sednem posthumanistycznej myśli filmu.

Jednak to nie tylko ciało widza staje się przestrzenią obcości. Snow kilkakrotnie przywołuje w tym kontekście także organiczny charakter obrazu filmo- 
wego. Powróćmy do ujęcia z finału. Stroboskopowe pulsowanie dźwięku i obrazu odnosi się wyraźnie do samej struktury filmu, którego odbiór opiera się przecież na iluzji wynikającej z niedoskonałości ludzkiego aparatu percepcyjnego. Widz „uzupełnia” migoczące obrazy o czynnik ruchu w momencie, w którym nie potrafi zarejestrować ich rzeczywistego, nieciągłego charakteru. Scalone ze sobą w jeden widok ziemia i niebo mogą być zatem metaforą samego kina. Podkreślają to obdarzone aurą niesamowitości zdjęcia, w których kamera kieruje się w swej nieustannej rotacji prosto ku słońcu - wypełniony bielą ekran staje się pusty jako przedstawienie, ale jednocześnie zostaje „nasycony” materialnością filmu. Ukazują się na nim niedoskonałości taśmy, zabrudzenia, plamy. Światło zostaje tu przedstawione jako czynnik aktywny, nie-ludzki aktor-demiurg powołujący do życia film na półprzezroczystej błonie, umożliwiającej z kolei doświadczenie kinowe. Jeśli krajobraz to szok niespójności przestrzeni i czasu, to filmowa reprezentacja jest prawdopodobnie najlepszym przykładem krajobrazu, w którym widz jest zmuszony do ciągłego łączenia ujęć, syntetyzowania z nich chwilowej, nietrwałej i umownej całości. Jeśli La Région centrale opowiada o czymkolwiek, to właśnie o tym procesie. Snow tworzy więc film wydający się komentarzem na temat kina - z jednej strony jako obrazu zdolności poznawczych człowieka, z drugiej jako podstawowej płaszczyzny poznania. Jak twierdzili André Bazin i Béla Balázs, to obrazy kinowe przedstawiają najbardziej intensywną rzeczywistość, obdarzoną zmysłową moca, niedostrzegalną poza salą kinową. Moc ta dotyczy nawet najbardziej trywialnych rzeczy, przez co stwarza trudny do uchwycenia, wizualny naddatek, który za Jeanem Epsteinem można by określić mianem ruchu kinematograficznego, nadającego żywotność materii nieorganicznej ${ }^{41}$. Nawet jeśli owo „kino-poznanie” dotyczy tylko obrazu fragmentarycznego, nie oznacza to, że jest pozorne. Przeciwnie, zmysłowe doświadczenie jest prawdziwe i oferuje dostęp do prawdziwej wiedzy, w obrębie której staje się możliwy ponowny namysł nad kategorią realizmu i automatyzmu w filmie.

Perspektywa La Région centrale to perspektywa maszynowego oka Ziemi, ale Ziemi procesualnej, Deleuzjańskiej Figury jako zmysłowej, wizualnej obecności. Przy tym Snow sugeruje, że widz jest nie tylko świadkiem tego „stawania się”, ale organicznym elementem ciągłej metamorfozy, w której podmiotowa spójność i odrębność zostają całkowicie zanegowane. Symbolizuje to maszyna umieszczona na kanadyjskim pustkowiu - „osi świata”. Maszyna nigdy nie pojawia się na ekranie, jest niewidzialna, a jednak stale obecna. Owa axis mundi wprawdzie nie wyznacza żadnego stabilnego miejsca, ale wytwarza pewne niewidoczne centrum ${ }^{42}$. Schollenberger twierdzi za Lyotardem, że krajobraz to doświadczenie rozpadu uniemożliwiające pomyślenie świata jako całości. Według mnie przywołana uprzednio zmysłowa obecność widza, jak również unaocznienie filmowej materii moga prowadzić do innego wniosku, mianowicie do rozpoznania, że destrukcja krajobrazu umożliwia dostęp do pewnej wiedzy. Wprawdzie nie jest to wiedza o niezależnym od podmiotu przedmiocie (ten bowiem nie istnieje), lecz o cielesnym doświadczeniu, którym jest spotkanie z tym, co radykalnie opiera się znaczeniu. To doświadczenie otwiera drogę do powolnej konstrukcji świata jako całości - nie na podstawie gotowego oryginału, ale kryzysu obrazu rozumianego jako przesilenie umożliwiające powtórną wiarę w koherencję i spójność świata. La Région centrale stanowi według mnie coś na kształt systemu naczyń połączonych, w którym zostaje zniesiona izolacja 
podmiotu i przedmiotu, ale nie na rzecz relatywizmu i mnożenia nowych perspektyw, lecz wspólnej odpowiedzialności za bycie w rzeczywistości, które można sobie uświadomić dopiero pod wpływem doświadczenia zmysłowego. Fantomowa obecność maszyny produkującej obrazy nie oznacza przecież nieobecności.

Elsaesser pisze o odpowiedzialności i przynależności do świata, odnosząc się do automatycznego wymiaru filmu zapewniającego o istnieniu jakiejś obiektywnej zewnętrzności oraz ukazującego paradoksalnie, że widz jest elementem tej zewnętrzności ${ }^{43}$. Virginia Woolf twierdzi w podobnym duchu, że filmowa maszyneria ma bezprecedensową zdolność ukazywania życia, jakie jest, wówczas gdy nie bierzemy w nim udziału ${ }^{44}$. Tak jak piękno płatków śniegu objawiające się w ich obojętności na istnienie człowieka u Bazina, życie to tyleż wyobcowuje widza, ile włącza go w sztafaż całej rzeczywistości, w której nie ma różnicy między pięknym i brzydkim, cennym i bezwartościowym, klamka i księżną ${ }^{45}$. Wydaje się, że poczucie przynależności do świata przez filmy takie jak La Région centrale jest w dobie antropocenu, katastrofy klimatycznej i pandemii - zjawisk ujawniających problemy globalnego kapitalizmu ${ }^{46}$ - doświadczeniem niezwykle cennym. Konieczność zaangażowania w świat - już nie w roli podmiotu władzy, ale jego organicznej części - będzie wymagała także redefinicji kina i filmu jako obszarów obcowania z tym światem. Być może przyjdzie nam także przemyśleć realistyczne teorie kina i afirmacyjny potencjał, który oferują. Jak zauważyła komentatorka myśli Bazina, jego posthumanistyczny realizm sprowadza się do wykraczającej poza izolację podmiotu miłości, której sednem jest spojrzenie ujmujące człowieka na równi ze zwierzętami, przedmiotami i przestrzenia, zasadniczo obce wobec ludzkich pragnieńn ${ }^{47}$.

Tak rozumianą obcość uwarunkowaną automatycznym spojrzeniem kamery dostrzegam w całej twórczości Snowa, przede wszystkim zaś w La Région centrale. Tytułowa przestrzeń centralna wymyka się ludzkiemu poznaniu, może nawet jest pusta, ale jak najbardziej istnieje. W geście porzucenia znaczenia Elsaesser dostrzega otwarcie na możliwość filmowego prezentowania świata, przy czym proces ten w przeciwieństwie do re-prezentacji - odbywałby się na drodze uobecnienia świata za pomocą obrazów: Automatyzm kinowego ruchu wymaga zupetnie innych [niż ludzkie] wspótrzędnych - takich, w których nasze organizmy i mózgi sa integralnym składnikiem świata, uwalniając nas od idei wnętrza, uleczając z rozłamów na podmiot i przedmiot, umyst $i$ ciało $^{48}$. Ekstatyczne doświadczenie La Région centrale polegałoby właśnie na wyjściu poza upraszczające dualizmy, ku odpowiedzialnej i etycznej obecności. Sposób tworzenia krajobrazu w filmie Snowa pokazuje, że wyobcowanie to zaledwie jeden z efektów tego działania, mogącego także prowadzić niespodziewanie do pełnej identyfikacji, takiej, która paradoksalnie wymaga porzucenia myślenia o sobie jako identyfikującym się podmiocie. Bezrefleksyjna kamera zostaje tu zestawiona z refleksyjnym krajobrazem, spójną przestrzenią rozciągającą się na ekranie i poza nim. Aparat niestrudzenie chwyta obrazy, za pomocą ciągłych rotacji i obrotów sugeruje opowieść o świecie, który nie wyczerpuje się w granicach ustanawianych przez kadry filmowe, lecz znajduje kontynuację w odczuwaniu widza zaangażowanego zmysłowo, rozpoznającego swoje ciało jako przestrzeń krajobrazu - nagłego wtargnięcia obcości i materialności. Zawieszone zostają rozróżnienia podmiotowe, a w przestrzeni centralnej sytuuje się niewidoczna, nieosobowa, panteistyczna świadomość kontemplująca samą siebie; podmiot rozciaga się na całym obwodzie koła, którego środek już dawno zostat opuszczony przez "„ja"49. 
${ }^{1}$ G. Deleuze, Francis Bacon. Logika wrażenia, tłum. A. Z. Jaksender, Wydawnictwo Eperons-Ostrogi, Kraków 2018, s. 173.

${ }^{2}$ E. Legge, Michael Snow: Wavelength, Afterall Books, London 2009, s. 12.

${ }^{3}$ E. Panofsky, Perspektywa jako "forma symboliczna", tłum. G. Jurkowlaniec, Wydawnictwa Uniwersytetu Warszawskiego, Warszawa 2008, s. 53.

${ }^{4}$ Sicinski wykorzystuje dwuznaczność angielskiego słowa dwell oznaczającego zarówno zamieszkiwanie, jak i rozmyślanie, dywagowanie. M. Sicinski, Michael Snow's "Wavelength" and the Space of Dwelling, "Qui Parle" 1999, t. 11, nr 2, s. 73.

${ }^{5}$ F. Leitner, On Robots and Turtles: A Posthuman Perspective on Camera and Image Movement after Michael Snow's "La Région centrale”, „Discourse” 2013, t. 35, nr 2, s. 267.

${ }^{6}$ Tamże, s. 265.

7 Tamże, s. 268.

8 Tamże, s. 269.

${ }^{9}$ Nagranie umieszczone najpierw na platformie YouTube zostało już usunięte. Zob. S. Messenger, Sea Turtle Finds Lost Camera, Films Itself Swimming, https://www.treehugger.com/natural-sciences/sea-turtle-findslost-camera-films-itself-swimmingvideo.html (dostęp: 9.03.2020).

${ }^{10}$ F. Leitner, dz. cyt., s. 270.

11 Tamże, s. 274.

12 R. Braidotti, Podmioty nomadyczne. Ucieleśnienie i różnica seksualna w feminizmie wspótczesnym, tłum. A. Derra, Wydawnictwa Akademickie i Profesjonalne, Warszawa 2009, s. 66.

${ }^{13}$ T. Elsaesser, European Cinema and Continental Philosophy: Film as Thought Experiment, Bloomsbury, New York 2019, s. 45.

${ }^{14}$ Tamże, s. 53. Elsaesser obrazuje uwage słynnym fragmentem z książki Bazina, w którym teoretyk pisał o samowystarczalności i autonomicznym pięknie kwiatu lub płatka śniegu, istniejących niejako w świecie równoległym, bez ingerencji człowieka, a nabierających szczególnej namacalności dopiero w obrazie filmowym.

15 Tamże, s. 27.

${ }^{16}$ P. Schollenberger, Odosobnienie. Próby dekonstrukcji krajobrazu, http://www.pismowidok.org/pl/archiwum/2014/8-powrot-krajobrazu/odosobnienie.-proby-dekonstrukcjikrajobrazu (dostęp: 19.03.2020).

17 Tamże.

${ }^{18}$ Tamże, s. 8.

19 Tamże.

${ }^{20}$ Tamże.
21 Tamże, s. 9.

22 P. Schollenberger, Krajobraz bezstronny - doświadczenie krajobrazu według Lyotarda, w: Krajobraz kulturowy, red. B. Frydryczak, M. Ciesielski, Wydawnictwo Poznańskiego Towarzystwa Przyjaciół Nauki, Poznań 2014, s. 102.

${ }^{23}$ Tamże, s. 104.

24 Tamże, s. 106.

${ }^{25}$ J.-F. Lyotard, Scapeland, w: tegoż, L'Inhumain. Causeries sur le temps, Éditions Galilée, Paris 1988, s. 194.

${ }^{26}$ Tenże, The Unconscious as Mise-en-scène, tłum. J. Maier, w: Acinemas: Lyotard's Philosophy of Film, red. G. Jones, A. Woodward, Edinburgh University Press, Edinburgh 2017, s. 52.

27 Tamże.

${ }^{28}$ Tamże, s. 53.

29 Tamże, s. 52.

${ }^{30}$ J.-F. Lyotard, Acinema, tłum. P. N. Livingston, w: Acinemas... dz. cyt., s. 39.

${ }^{31}$ P. Schollenberger, Odosobnienie... dz. cyt.

32 J.-F. Lyotard, The Unconscious as Mise-en-scène... dz. cyt., s. 53.

${ }^{33}$ G. Deleuze, dz. cyt., s. 155.

34 Tamże, s. 156.

35 Tamże, s. 156-157.

36 Tamże, s. 156.

37 Tamże, s. 255.

${ }^{38}$ Koncepcja Deleuze'a jest wywiedziona z rozróżnienia na figuratywne i figuralne, zaproponowanego przez Lyotarda. Figuratywne byłoby to, co przedstawiajacce, narracyjne (nawet $\mathrm{w}$ najprostszym sensie), figuralne to, co jest obecne, ale wymyka się znaczeniu. Zob. J.-F. Lyotard, Discours, Figure, Klincksieck, Paris 1971.

39 Tamże, s. 163-164.

40 Tamże, s. 166.

${ }^{41}$ Z. Czeczot-Gawrak, Współczesna francuska teoria filmu, Zakład Narodowy im. Ossolińskich - Wydawnictwo Polskiej Akademii Nauk, Wrocław 1982, s. 39.

42 Thierry de Duve pisze o tajemniczym obszarze centralnym tak: centrum centralnego regionu przypomina czarna dziurę. Jego siła grawitacyjna jest tak silna, że wszystko w otoczeniu zostaje przez nie wchtonięte, jednak ono samo pozostaje mroczne, niewidzialne, nieświadome tego, co robi. Oko maszynerii widzi wszystko $z$ wyjatkiem samego siebie. W przeciwieństwie do Kartezjańskiego i Kantowskiego podmiotu nie jest refleksyjne. T. de Duve, Michael Snow: The Deictics of Experience and Beyond, "Parachute” 1995, nr 78, s. 9. Cyt. za: P. Schollenberger, Odosobnienie... dz. cyt. (dostęp: 19.03.2020). 
${ }^{43}$ T. Elsaesser, dz. cyt., s. 45.

44 Tamże, s. 44.

45 Tamże, s. 51.

${ }^{46}$ Esej ten kończę w czasie izolacji społecznej wywołanej pandemią COVID 19.

47 J. Fay, Seeing/Loving Animals: André Bazin's Posthumanism, "Journal of Visual Culture" 2008, t. 7, nr 1, s. 51 .
${ }^{48}$ T. Elsaesser, dz. cyt., s. 54.

${ }^{49}$ G. Deleuze, F. Guattari, Anty-Edyp, tłum. T. Kaszubski, Wydawnictwo Krytyki Politycznej, Warszawa 2017, s. 26.

\section{Aleksander Kmak}

Filmoznawca i krytyk sztuki współczesnej; w Instytucie Kultury Polskiej Uniwersytetu Warszawskiego przygotowuje rozprawę doktorską o kinie nieprzyjemności i zmysłowej teorii filmu. Publikował między innymi w „Widoku”, „Kwartalniku Filmowym”, „Ekranach” i „Pleografie”; stale współpracuje z magazynem „Szum”. Współredagował książkę Cięcie ciat. Ruchome obrazy (2018).

\section{Bibliografia}

Barthes, R. (1971). Trzeci sens. Poszukiwania na podstawie kilku fotogramów z filmów S. N. Eisensteina. Kino, 11, ss. 37-41.

Braidotti, R. (2009). Podmioty nomadyczne. Ucieleśnienie i różnica seksualna đo feminizmie zespótczesnym (thum. A. Derra). Warszawa: Wydawnictwa Akademickie i Profesjonalne.

Czeczot-Gawrak, Z. (1982). Współczesna francuska teoria filmu. Wrocław: Zakład Narodowy im. Ossolińskich - Wydawnictwo Polskiej Akademii Nauk.

Deleuze, G., Guattari, F. (2017). Anty-Edyp (thum. T. Kaszubski). Warszawa: Wydawnictwo Krytyki Politycznej.

Deleuze, G. (2018). Francis Bacon. Logika wrażenia (tłum. A. Z. Jaksender). Kraków: Wydawnictwo Eperons-Ostrogi.

Elsaesser, T. (2019). European Cinema and Continental Philosophy: Film as Thought Experiment. New York: Bloomsbury.

Fay, J. (2008). Seeing/Loving Animals: André Bazin's Posthumanism. Fournal of Visual Culture, 7 (1), ss. 41-64.

Legge, E. (2009). Michael Snow: Wavelength. London: Afterall Books.

Leitner, F. (2013). On Robots and Turtles: A Posthuman Perspective on Camera and Image Movement after Michael Snow's „La Région centrale”. Discourse, 35 (2), Ss. $263-277$.

Lyotard, J. F. (1988). L'Inhumain. Causeries sur le temps. Paris: Éditions Galilée.

Jones, G., Woodward, A. (red.) (2017). Acinemas: Lyotard's Philosophy of Film. Edinburgh: Edinburgh University Press.

Marks, L. U. (2002). Touch: Sensuous Theory and Multisensory Media. Minneapolis: University of Minnesota Press. 
Messenger, S. (2010, 9 czerwca). Sea Turtle Finds Lost Camera, Films Itself Swimming. treehugger.com. https://www.treehugger.com/natural-sciences/sea-turtle-findslost-camera-films-itself-swimming-video.html

Mitchell, W. J. T. (2015). Czego chca obrazy? Pragnienia przedstawień, życie $i$ miłości obrazów (thum. Ł. Zaremba). Warszawa: Narodowe Centrum Kultury.

Panofsky, E. (2008). Perspektywa jako „forma symboliczna” (thum. G. Jurkowlaniec). Warszawa: Wydawnictwa Uniwersytetu Warszawskiego.

Schollenberger, P. (2014). Krajobraz bezstronny - doświadczenie krajobrazu według Lyotarda. W: B. Frydryczak, M. Ciesielski (red.), Krajobraz kulturowy (wyd. 1, ss. 99--114). Poznań: Wydawnictwo Poznańskiego Towarzystwa Przyjaciół Nauki.

Schollenberger, P. (2014). Odosobnienie. Próby dekonstrukcji krajobrazu. Widok. Teorie $i$ Praktyki Kultury Popularnej, 8. http://www.pismowidok.org/pl/archiwum/2014/8-powrot-krajobrazu/odosobnienie.-proby-dekonstrukcjikrajobrazu

Sicinski, M. (1999). Michael Snow's „Wavelength” and a Space of Dwelling. Qui Parle, 11 (2), SS. 59-88.

Keywords:

film theory;

avant-garde cinema;

Michael Snow;

landscape;

Anthropocene;

sensuous film theory

\author{
Abstract \\ Aleksander Kmak
}

The Crisis of Representation, Earth-Landscape and Post-humanist Pantheism in Michael Snow's La Région centrale

The main subject of the essay is Michael Snow's La Région centrale. Referencing various writings on the film, the author highlights areas that have not been tackled by scholars: the sensuous character of the film experience and its consequences for cinema's status as a sphere of the cognition of reality. La Région centrale is juxtaposed with Gilles Deleuze's concepts of painterly catastrophe and diagram in order to show how the experience of landscape becomes a post-humanist project of creating the whole new world, where existent dualisms of body-mind, subject-object or human-animal are completely overthrown. This interpretation is accompanied by a reflection on the cinema's role during the age of Anthropocene and a re-affirmation of realism in film theory. 